\title{
Characterization of the infectious hematopoietic necrosis virus glycoprotein using neutralizing monoclonal antibodies
}

\author{
Chienjin Huang ${ }^{1}$, Maw-Sheng Chien ${ }^{1}$, Marsha Landolt ${ }^{1}$, James Winton ${ }^{2, *}$ \\ ${ }^{1}$ School of Fisheries, University of Washington, Seattle, Washington 98195, USA \\ ${ }^{2}$ National Fisheries Research Center, BIdg 204 Naval Station, Seattle, Washington 98115, USA
}

\begin{abstract}
To study the antigenic nature of the glycoprotein ( $G$ protein) of infectious hematopoietic necrosis virus (IHNV), 31 neutralizing monoclonal antibodies (MAbs) were produced against a reference isolate of the virus. The MAbs were compared using a neutralization assay, an enzyme-linked immunosorbent assay (ELISA), and by immunoblotting of the $G$ protein in the native, reduced, and deglycosylated forms. Hybridoma culture fluids of the various MAbs could be diluted from 1:2 to 1:512 and still completely neutralize $1 \times 10^{4}$ plaque-forming units of IHNV. Similarly, the end point dilutions that produced optical density readings of 0.1 or greater in the ELISA were 1:40 to 1:10240. Western blotting showed that all of the MAbs reacted with the G protein in the unreduced (i.e. native) conformation; however, only 9 nine of the MAbs were able to react with the G protein following reduction by 2 -mercaptoethanol. Deglycosylation of the protein did not influence the binding ability of any of the MAbs. These data indicate that all the MAbs recognized amino acid sequences on the protein itself and that the IHNV glycoprotein contains linear as well as conformation-dependent neutralizing epitopes. When rainbow trout Oncorhynchus mykiss fingerlings were passively immunized with MAbs against either a linear or a conformation-dependent epitope, the fish were protected against challenge with wild-type IHNV.
\end{abstract}

KEY WORDS: Rhabdovirus · Salmon · Trout · Antigen

\section{INTRODUCTION}

Infectious hematopoietic necrosis virus (IHNV) is a fish rhabdovirus that produces an acute disease (IHN) resulting in destruction of the hematopoietic tissues of the kidney and spleen and in the loss of millions of salmon and trout each year (Wolf 1988). Because IHN is untreatable, control methods have relied on prevention by improved water quality, disinfection of eggs, sanitation of fish culture facilities, and destruction of infected fish populations (Winton 1991).

Several vaccines have been developed and tested for controlling IHN, including killed and attenuated preparations (Leong et al. 1988). Engelking \& Leong (1989) showed that the IHNV glycoprotein (G protein) alone

\footnotetext{
-Addressee for correspondence
}

was able to induce neutralizing antibodies in rabbits and to immunize salmonids against challenge with the virus. The newest vaccines against IHNV are subunit vaccines developed by cloning regions of the glycoprotein gene of IHNV into Escherichia coli (Gilmore et al. 1988, Xu et al. 1991) or baculovirus (Koener \& Leong 1990) expression systems. Laboratory and field trials showed that a subunit vaccine could stimulate protective immunity in trout against IHNV (Leong et al. 1992). Similarly, the glycoprotein of viral hemorrhagic septicemia virus (VHSV) expressed in Escherichia coli was shown to be immunogenic in trout (Lorenzen et al. 1993).

Monoclonal antibodies (MAbs) have been useful in the study of rhabdovirus glycoprotein structure and function and in defining neutralizing epitopes on rabies virus (Lafon et al. 1983, Benmansour et al. 1991) and vesicular stomatitis virus (VSV; Lefrancois \& Lyles 
1982, Luo et al. 1988). Among fish rhabdoviruses, neutralizing MAbs have been developed against isolates of IHNV (Winton et al. 1988, Ristow \& Arnzen de Avila 1991 ) and VHSV (Lorenzen et al. 1988, 1990). In addition to serving as reagents for determining the antigenic diversity among field isolates of IHNV, these MAbs have been used to select variants of the virus that were attenuated in virulence (Roberti et al. 1991), to develop a preliminary epitope map of the IHNV glycoprotein (Xu et al. 1991), and to passively protect fish against VHSV (Lorenzen et al. 1990).

The purpose of this research was to produce a large panel of MAbs against a single reference isolate of IHNV that would recognize the various neutralizing epitopes on the viral glycoprotein to further characterizc the nature of these antigenic determinants.

\section{MATERIALS AND METHODS}

Cells and virus. Chinook salmon embryo (CHSE214) cells (Lannan et al. 1984) were maintained in minimum essential medium (MEM, Gibco BRL, Grand island, NY, USA) supplemented with $10 \%$ fetal bovine serum (Gibco), $2 \mathrm{mM}$ L-glutamine (Gibco), $0.3 \%$ tryptose phosphate broth (Difco Lab., Detroit, MI, USA),

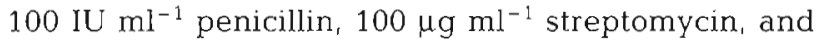
$100 \mu \mathrm{g} \mathrm{ml}^{-1}$ gentamicin sulphate (U.S. Biochem. Corp., Cleveland, OH, USA) at pH 7.5. For the neutralization assay, we used epithelioma papulosum cyprini (EPC) cells (Fijan et al. 1983).

We used the Western Regional Aquaculture Center (WRAC) reference isolate of IHNV recovered in 1982 from rainbow trout fry at a commercial facility in the Hagerman Valley, ID, USA. Monolayer cultures of CHSE-214 cells were infected with IHNV at a multiplicity of infection of 0.001 plaque-forming units (PFU) per cell and incubated at $15^{\circ} \mathrm{C}$ for $7 \mathrm{~d}$. Culture supernatant was harvested and centrifuged at $10000 \times g$ for 20 min at $4^{\circ} \mathrm{C}$ to remove the cell debris. Viral purification was performed on discontinuous and continuous sucrose gradients according to the procedures described by Hsu et al. (1986) and Kurath \& Leong (1985).

Production of hybridomas and monoclonal antibodies. Adult female BALB/c mice were immunized by intraperitoneal injection with $0.5 \mathrm{ml}$ of a mixture of purified IHNV and an equal volume of Freund's complete adjuvant. A similar inoculation was given 3 wk later using Freund's incomplete adjuvant. After an additional 4 wk, the immunized mice received a final booster by intravenous injection in the tail vein with $0.2 \mathrm{ml}$ of diluted IHNV antigen without adjuvant. The fusion was carried out $3 \mathrm{~d}$ after the final injection using methods described by Mishell \& Shiigi (1980) and Lane (1985). Briefly, fusion between IHNV-immunized spleen cells and SP2/0 Ag-14 myeloma cells was induced with $50 \%$ polyethylene glycol 1500 and 4000 (4:1). Hybridomas secreting IHNV-specific neutralizing antibody were selected by a micro-neutralization assay (Winton et al. 1988) and positive clones were subcloned twice by limiting dilution and then expanded in culture flasks for in vitro production of antibody. MAb class and subclass were determined by enzyme-linked immunosorbent assay (ELISA) using mouse sub-isotyping kit (Bio-Rad Laboratories, Richmond, CA, USA).

Neutralization assay. Neutralizing antibody titers were determined by a modification of the method of Rovozzo \& Burke (1973). Briefly, serial 2-fold dilutions of the hybridoma fluids were prepared in 96-well mirrntiter plates with MEM and reacted with equal volumes of a suspension containing $1 \times 10^{4} \mathrm{PFU} \mathrm{ml}^{-1}$ of IHNV. After $1 \mathrm{~h}$ incubation at $15^{\circ} \mathrm{C}$, titrations were performed using monolayers of EPC cells. The neutralization titer was expressed as the last dilution of the hybridoma culture supernatant completely neutralizing all the input virus in the well.

Enzyme-linked immunosorbent assay. Ninety-six well, Immulon I MicroElisa plates (Dynatech Lab. Alexandria, VA, USA) were coated with $0.5 \mu \mathrm{g}$ of purified IHNV per well in carbonate buffer, pH 9.6, and allowed to incubate overnight at $4{ }^{\circ} \mathrm{C}$. Plates were washed 3 times with phosphate buffered saline (PBS) containing $0.05 \%$ Tween 20 (PBST), and then $50 \mu \mathrm{l}$ of test hybridoma supernatant was added. After $2 \mathrm{~h}$ incubation at room temperature (RT), the plates were washed 3 times with PBST. Next, $50 \mu$ l of diluted horseradish peroxidase (HRP)-conjugated goat anti-mouse immunoglobulin (Ig) (Hyclone Laboratories, Logan, UT, USA) was added to each well, and the plates were incubated for $60 \mathrm{~min}$ at RT. After 5 washes, the chromogen, consisting of $1 \mathrm{mM}$ ABTS $\left[2,2^{\prime}\right.$-azino-bis (3-ethylbenzthiazoline-6-sulfonic acid)] and $0.03 \%$ hydrogen peroxide $\left(\mathrm{H}_{2} \mathrm{O}_{2}\right)$ in $0.1 \mathrm{M}$ sodium citrate buffer, $\mathrm{pH} 4.2$, was added and allowed to react for $30 \mathrm{~min}$ at RT The absorbance of the samples was monitored at $405 \mathrm{~nm}$ in a microplate reader (Bio-Tek Instruments, Winooski, VT, USA), and the ELISA titer was expressed as the last dilution of the hybridoma culture supernatant that produced an optical density (OD) reading equal to or greater than 0.1 OD units.

Preparation of samples for electrophoresis. The structural proteins of IHNV were separated by electrophoresis under either reducing or non-reducing conditions. The viral glycoprotein was deglycosylated by means of an enzyme preparation containing equal activities of endoglycosidase $F$ and glycopeptidase $F$ (ENDO-F; Sigma Chemical Co., St. Louis, MO, USA; Plummer et al, 1984). Purified virus $\left(50 \mu \mathrm{g} \mathrm{m} \mathrm{m}^{-1}\right)$ was incubated overnight at $37^{\circ} \mathrm{C}$ with 2 units $\mathrm{ml}^{-1}$ of 
and cloned (Table 1). Culture fluids from the 31 hybridomas could be diluted between $1: 2$ and $1: 512$ and still completely neutralize infectivity in an equal volume of a suspension containing $1 \times 10^{4} \mathrm{PFU} \mathrm{ml}^{-1}$ of

A

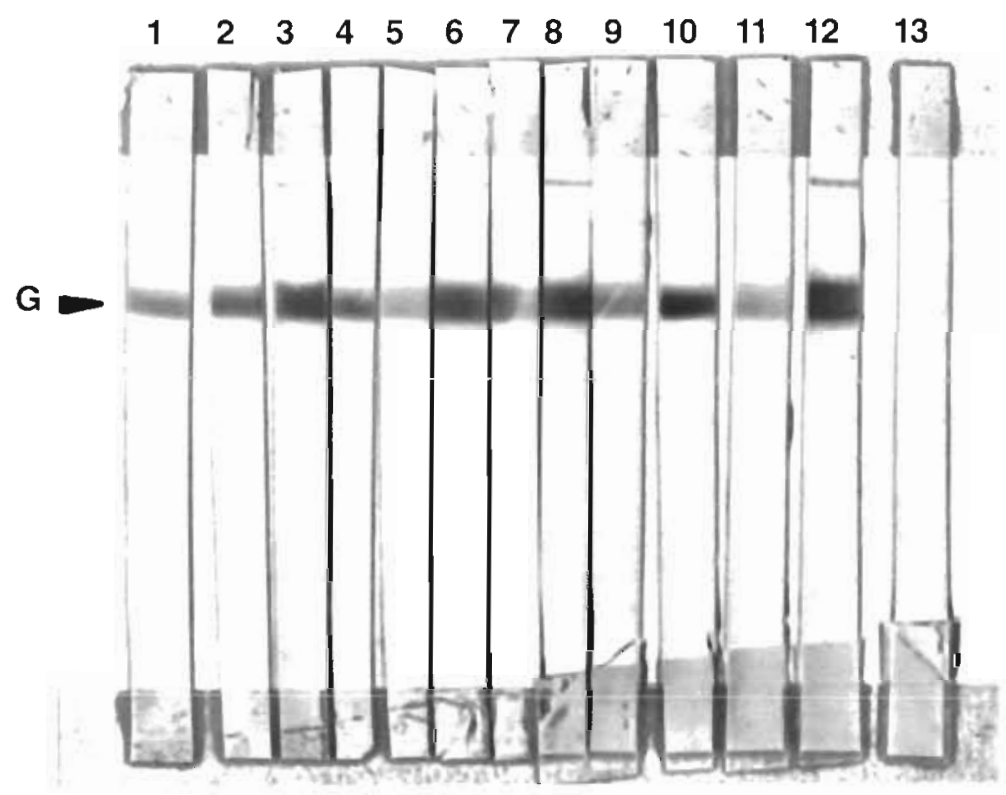

B

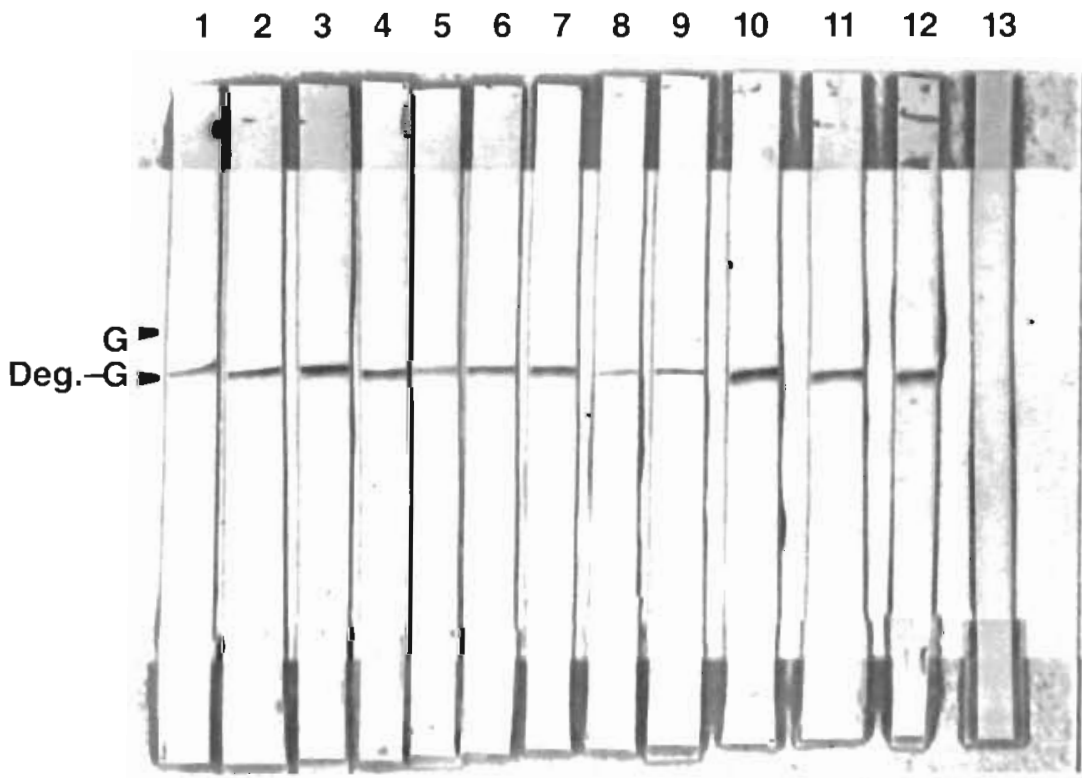

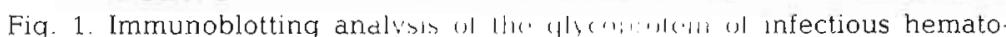
poietic necrosis virus (IHNV) using 12 neutralizing monoclonal antibodies (MAbs). All of the MAbs reacted with the glycoprotein in (A) the native (unreduced) conformation or (B) the native conformation following deglycosylation. Strips 1 to 12 were developed using cell culture fluids containing MAbs $1 \mathrm{E} 11,1 \mathrm{H} 8,1 \mathrm{H} 10,2 \mathrm{C} 5,2 \mathrm{E} 9,3 \mathrm{~F} 12,3 \mathrm{H} 12,5 \mathrm{~A} 6,5 \mathrm{G} 3,6 \mathrm{~A} 7,6 \mathrm{D} 7$ and $6 \mathrm{H} 7$, respectively. Strip 13 was developed using culture fluid from SP2 myeloma cultures as a control. The positions of the IHNV glycoprotein in the native (G) and deglycosylated (Deg.-G) forms are shown
IHNV. The end-point dilutions to produce an OD reading of 0.1 or greater in the ELISA ranged from 1:40 to 1:10240. The Ig class or subclass and light chain type of each of the 31 MAbs were determined by ELISA About half of the clones (15 of 31) produced IgM antibodies while the remainder were IgG1 (2), IgG2a (9), IgG2b (3), or IgG3 (2). While there did not appear to be a significant relationship between the class of antibody and the neutralization or ELISA titers, in general, those MAbs with a high neutralizing ability also had a high binding titer.

\section{Immunoblotting of IHNV glycoprotein}

The specificity of each MAb for the reduced, unreduced, and deglycosylated forms of the IHNV glycoprotein was determined by immunoblotting. All of the MAbs reacted with the $G$ protein in the unreduced (native) conformation and MAbs 1H12, 2H12, 2D3, 3B12, 4E10, $5 \mathrm{~A} 6,6 \mathrm{~A} 7,6 \mathrm{H} 7$, and $6 \mathrm{~A} 12$ were able to bind to the $G$ protein after reduction of disulfide bonds indicating these nine MAbs were directed at linear determinants on the molecule (Table 1). Treatment of the purified virus with ENDO-F prior to electrophoresis and blotting did not affect the ability of any of the MAbs to bind to the G protein (Fig. 1). As expected, the removal of carbohydrates reduced the molecular weight of the $G$ protein and sharpened the bands (Fig. 1). None of the MAbs reacted with other structural proteins of the virus.

\section{Passive protection of fish}

MAbs $1 \mathrm{H} 8$ and $6 \mathrm{~A} 7$ were concentrated and purified from culture supernatants in order to determine the protective ability of these preformed neutralizing antibodies in fish. Both MAbs conferred a significant degree of protection against waterborne challenge (Table 2). The duplicate group of 25 fish that received MAb $1 \mathrm{H} 8$ averaged $98 \%$ survivors and the duplicate group receiving MAb $6 A 7$ averaged $94 \%$ survivors. These results were similar to the average survival of fish in the control group injected with PBS but not 
IHNV within commercial trout facilities (S. LaPatra unpubl. obs.)

Our results provide new information about the nature of the epitopes on the IHNV glycoprotein that stimulate neutralizing antibodies. In addition, the MAbs developed in this study will serve as useful tools for more precisely locating these epitopes by sequencing the G protein of IHNV mutants that escape neutralization. More detailed knowledge of the IHNV neutralizing epitope structure will aid in the design of IHN vaccines, which are needed for control of this disease in aquaculture.

Acknowledgements. We thank Cindy Arakawa and William Batts, National Fisheries Research Center, Seattle, WA, for valuable technical assistance. We also thank Drs S. Cho Chou Kuo and Lee Ann Campbell, Department of Kathobiology, University of Washington, Seattle, WA, for excellent advice during the course of this project. This material is based on work supported by the Cooperative State Research Service, U.S. Department of Agriculture, through the Western Regional Aquaculture Center under Agreements No. 89$38500-4287,90-38500-5025,91-38500-6078$, and 92-385007195.

\section{LITERATURE CITED}

Benmansour, A., Leblois, H., Coulon, P., Tuffereau, C., Gaudin, Y., Flamand, A., Lafay, F. (1991). Antigenicity of rabies virus glycoprotein. J. Virol. 65: 4198-4203

Dietzschold, B., Gore, M., Marchadier, D., Niu, H.-S., Bunschoten, H. M., Otvos, L. Jr, Wunner, W. H., Ertl, H. C. Osterhaus, A. D. M. E., Koprowski, H. (1990). Structural and immunological characterization of a linear virus-neutralizing epitope of the rabies virus glycoprotein and its possible use in a synthetic vaccine. J. Virol. 64: 3804-3809

Dubois-Dalcq, M., Holmes, K. V., Rentier, B. (1984). An overview of the assembly of enveloped RNA viruses. In: Assembly of enveloped RNA viruses. Springer, New York p. $1-20$

Engelking, H. M., Leong, J. C. (1989). The glycoprotein from infectious hematopoietic necrosis virus elicits neutralizing antibody and protective responses. Virus Res. 13: 213-230

Ey, P. L., Prowse, S. J., Jenkin, C. R. (1978). Isolation of pure $\lg _{1}, \quad \operatorname{IgG}_{2 \mathrm{~A}}$ and $\lg _{2 \mathrm{~B}}$ immunoglobulins from mouse serum using protein A-Sepharose. Immunochemistry 15: $429-436$

Fijan, N., Sulimanovic, D., Bearzotti, M., Muzinic, D., Zwillenberg, L. O., Chilmonczyk, S., Vautherot, J F., de Kinkelin, P. (1983). Some properties of the Epithelioma papulosum cyprini (EPC) cell line from carp Cyprinus carpio. Annls Virol. Inst. Pasteur 134: 207-220

Gilmore, R. D., Engelking, H. M., Manning, D .S., Leong, J. C. (1988). Expression in Escherichia coli of an epitope of the glycoprotein of infectious hematopoietic necrosis virus protects against viral challenge. Bio/Technol. 6: 295-300

Grigera, P. R., Mathieu, M. E., Wagner, R. R. (1991). Effect of glycosylation on the conformational epitopes of the glycoprotein of vesicular stomatitis virus (New Jersey serotype). Virology 180: 1-9

Hongo, S., Sugawara, K., Homma, M. Nakamura, K. (1986). The functions of oligosaccharide chains associated with influenza $C$ viral glycoproteins. II. The role of carbohy- drates in the antigenic properties of influenza $\mathrm{C}$ viral giycoproteins. Arch. Virol. 89: 189-201

Hsu, Y. L., Engelking, H. M., Leong, J. C. (1986). Occurrence of different types of infectious hematopoietic necrosis virus in fish. Appl environ. Microbiol. 52: 1353-1361

Koener, J. F., Leong, J. C. (1990). Expression of the glycoprotein gene from a fish rhabdovirus by using baculovirus vectors. J. Virol. $64: 428-430$

Kurath, G., Leong, J. C. (1985). Characterization of infectious hematopoietic necrosis virus mRNA species reveals a nonvirion rhabdovirus protein. J Virol. 53: 462-468

Laemmli, U. K. (1970). Cleavage of structural proteins during the assembly of the head of bacteriophage T4. Nature 227: $680-685$

Lafon, M., Wiktor, T., Macfarian, R. I. (1983). Antigenic sites on the CVS rabies virus glycoprotein: analysis with monoclonal antibodies. J. gen. Virol. 64: 843-851

Lane, R. D. (1985). A short-duration polyethylene glycol fucion terhnirue for increasing production of monoclonal antibody-secreting hybridomas. J. Immunol. Meth. 81: $223-228$

Lannan, C. N., Winton, J. R., Fryer, J. L. (1984). Fish cell lines: establishment and characterization of nine cell lines from salmonids. In Vitro 20: 671-676

Lefrancois, L., Lyles, D. S. (1982). The interaction of antibody with major surface glycoprotein of vesicular stomatitis virus. I. Analysis of neutralizing epitopes with monoclonal antibodies. Virology 121.151-167

Leong, J. C., Anderson, E., Bootiand, L., Chen, L., Drolet, B., Engelking, H. M., Mason, C., Mourich, D., Johnson, K., Trobridge, G., Wirkkula, J. (1992). Biotechnological approaches to development of salmonid fish vaccines. In: Kimura, T. (ed.) Proceedings of the Oji international symposium on salmonid diseases. Hokkaido University Press, Sapporo, p. 250-255

Leong, J. C., Fryer, J. L., Winton, J. R. (1988). Vaccination against infectious hematopoietic necrosis. In: Ellis, A. E. (ed.) Fish vaccination. Academic Press, New York, p. $193-203$

Lorenzen, N., Olesen, N. J., Jørgensen, P. E. V. (1988). Production and characterization of monoclonal antibodies to four Egtved virus structural proteins. Dis. aquat. Org. 4: $35-42$

Lorenzen, N., Olesen, N. J., Jørgensen, P. E. V. (1990). Neutralization of Egtved virus pathogenicity to cell cultures and fish by monoclonal antjbodies to viral $G$ protein. J. gen. Virol. 71: $561-56$ ?

Lorenzen, N., Olesen, N. J., Jorgensen, P. E. V., Etzerodt, M. Holtet, T L., Thogersen, H. C. (1993). Molecular cloning and expression in Escherichia coli of the glycoprotein gene of VHS virus, and immunization of rainbow trout with the recombinant protein. J gen. Virol. 74 : $623-630$

Luo, L., Li, Y., Snyder, R. M., Wagner, R. R. (1988). Point mutations in glycoprotein gene of vesicular stomatitis virus (New Jersey serotype) selected by resistance to neutralization by epitope-specific monoclonal antibodies. Virology 163: 341-348

Machamer, C. E., Rose, J. K. (1988). Vesicular stomatitis virus $G$ proteins with altered glycosylation sites display temperature sensitive intracellular transport and are subject to aberrant intermolecular disulfide bonding. $J$ biol. Chem. 263: $5955-5960$

Mishell, B. B., Shiigi, S. M. (1980). Selected methods in cellular immunology. Freeman, San Francisco

Plummer, T H. Jr, Elder, J. H., Alenander, S., Phelan, A. W., Tarentino, A. L. (1984). Demonstration of peptide: $N$. 
glycosidase $\mathrm{F}$ activity in endo-2-N-acetylglucosaminidase F preparations. J. biol. Chem. 259: 10700-10704

Ristow, S. S., Arnzen de Avila, J. (1991). Monoclonal antibodies to the glycoprotein and nucleoprotein of infectious hematopoietic necrosis virus (IHNV) reveal differences among isolates of the virus by fluorescence, neutralization and electrophoresis. Dis. aquat. Org. 11: 105-115

Roberti, K. A., Winton, J. R., Rohovec, J. S. (1991). Variants of infectious hematopoietic necrosis virus selected with glycoprotein-specific monoclonal antibodies. In: Proceedings of the second international symposium on viruses of lower vertebrates. Oregon State University Press, Corvallis, p. $33-42$

Rovozzo, G. C., Burke, C. N. (1973). A manual of basic virological techniques. Prentice-Hall, Englewood Cliffs

Towbin, H., Staehelin, T., Gordon, J. (1979). Electrophoretic transfer of proteins from polyacrylamide gels to nitrocellu-

Responsible Subject Editor: F. M. Hetrick, College Park, Maryland, USA lose sheets: Procedure and some applications. Proc. natl Acad. Sci. U.S.A. 76: 4350-4354

Winton, J. R. (1991). Recent advances in detection and control of infectious hematopoietic necrosis virus in aquaculture. A. Rev. Fish Dis. 1: 83-93

Winton, J R., Arakawa, C. K., Lannan, C. N., Fryer, J L. (1988). Neutralizing monoclonal antibodies recognize antigenic variants among isolates of infectious hematopoietic necrosis virus. Dis. aquat. Org. 4: 199-204

Wolf, K. (1988) Infectious hematopoietic necrosis. In: Fish viruses and fish viral diseases. Cornell University Press, Ithaca, p. 83-114

Xu, L., Mourich, D. V., Engelking, H. M., Ristow, S., Arnzen, J., Leong, J. C. (1991), Epitope mapping and characterization of the infectious hematopoietic necrosis glycoprotein, using fusion proteins synthesized in Escherichia coli. J. Virol. 65: 1611-1615

Manuscript first received: June 14, 1993

Revised version accepted: August 31, 1993 